\title{
EOSINOPHILIC GRANULOMATOSIS WITH POLYANGIITIS: DIAGNOSTIC DILEMMAS
}

\author{
Delia Tulbă${ }^{1}$, Răzvan Adrian Ionescu, ${ }^{1,2}$, Daniela Gologanu ${ }^{1}$, Marius Ioan Balea ${ }^{1}$, \\ Simona Caraiola ${ }^{1,2}$ \\ ${ }^{1}$ Internal Medicine Department, Colentina Clinical Hospital, Bucharest, Romania \\ "Carol Davila" University of Medicine and Pharmacy, Bucharest, Romania \\ Correspondence to: Delia Tulbă, MD \\ Address: Neurology Department, Colentina Clinical Hospital, 19-21 Ștefan cel Mare Street, \\ Sector 2, Bucharest, Romania \\ E-mail: tulba_delia@yahoo.com
}

\begin{abstract}
Introduction. Eosinophilic granulomatosis with polyangiitis (EGPA), formerly known as Churg-Strauss syndrome, is a systemic vasculitis of the small vessels that often associates asthma and blood/tissue eosinophilia.
\end{abstract}

Case presentation. A 58-year-old woman was admitted to our hospital for progressive exertional dyspnea. She had been diagnosed with asthma three years earlier. Recent multiple thoracic computed tomography scans displayed non-fixed interstitial lung abnormalities, whereas the infectious workup (HIV, parasites) was negative.

On admission, the clinical examination noted prolonged expiratory phase. Paraclinical tests revealed biological inflammatory syndrome, eosinophilia, polyclonal hypergammaglobulinemia, elevated total IgE level, negative anti-neutrophil cytoplasmic antibodies and proteinuria of nephritic pattern.

The pulmonary evaluation reconfirmed the obstructive ventilatory dysfunction and interstitial lung abnormalities - interlobular septal thickening and diffuse ground-glass opacification. The histopathological examination of a transbronchial biopsy specimen identified leukocytoclastic necrotizing vasculitis and tissue eosinophilia.

Provided the clinical and paraclinical setting, specifically the asthma, blood and extravascular eosinophilia, paranasal sinus abnormalities, non-fixed pulmonary infiltrates and the histopathologically confirmed necrotizing vasculitis, the diagnosis of EGPA seemed appropriate.

Conclusion. In the absence of diagnostic criteria, EGPA diagnosis is often challenging. Although certain clinical and imaging features could assist the diagnosis, biopsy remains the diagnostic gold standard.

In the setting of lung involvement, open lung biopsy is usually required for EGPA 


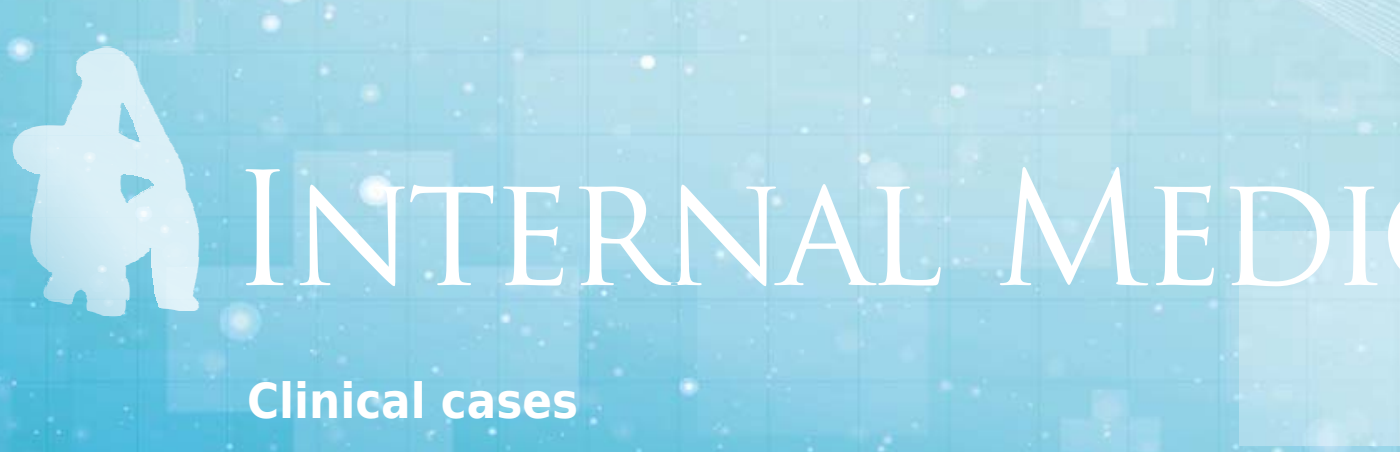

histopathological proof, but few cases diagnosed by transbronchial biopsy have been reported. This method often identifies discrete, nonspecific lesions or an incomplete spectrum of pathognomonic abnormalities but has the advantage of minimal invasivity that justifies its use as an alternative diagnostic technique.

Keywords: eosinophilic granulomatosis with polyangiitis, Churg-Strauss syndrome, transbronchial biopsy, vasculitis, ANCA.

\section{Rezumat}

Introducere. Granulomatoza eozinofilică cu poliangeită (GEPA), cunoscută ca sindrom Churg-Strauss, este o vasculită sistemică a vaselor mici ce asociază frecvent astm bronșic și eozinofilie serică/tisulară.

Prezentare de caz. O pacientă în vârstă de 58 de ani, cunoscută cu astm bronșic de circa trei ani, s-a prezentat în clinica noastră pentru dispnee progresivă de efort. Recent efectuase tomografii toracice repetate, ce au evidențiat infiltrat pulmonar interstițial fugace, iar bilanțul infecțios (HIV, parazitoze) a fost negativ.

La internare, la examenul clinic am remarcat expir prelungit. Bilanțul paraclinic a identificat sindrom biologic inflamator, eozinofilie, hipergamaglobulinemie policlonală, IgE serică crescută, anticorpi anticitoplasmă neutrofilică negativi, proteinurie cu pattern nefritic.

Evaluarea pneumologică a reconfirmat disfuncția ventilatorie obstructivă și existența leziunilor pulmonare interstițiale - îngroșarea septurilor interlobulare și arii de transparență difuză "în geam mat". Examenul histopatologic al probei obținute prin biopsie transbronșică a evidențiat eozinofilie tisulară și vasculită necrotizantă și leucocitoclazică.

Dat fiind contextul clinico-paraclinic, în speță prezența astmului bronșic, a eozinofiliei, rinosinuzitei polipoase, afectării pulmonare interstițiale fugace și a vasculitei necrotizante confirmate histopatologic, am considerat plauzibil diagnosticul de GEPA.

Concluzii. În absența criteriilor de diagnostic, diagnosticarea GEPA poate reprezenta o provocare. Deși anumite caracteristici clinico-paraclinice pot orienta diagnosticul, biopsia rămâne standardul de aur al diagnosticului.

Implicarea pulmonară necesită de obicei biopsie pulmonară deschisă pentru dovada histopatologică a GEPA, însă au fost raportate câteva cazuri diagnosticate prin biopsie transbronșică. Această metodă surprinde deseori leziuni discrete, nespecifice sau un spectru incomplet de modificări patognomonice, însă prezintă avantajul minimei invazivități ce justifică folosirea ei ca metodă alternativă de diagnostic. 


\section{Introduction}

Eosinophilic granulomatosis with polyangiitis (EGPA), formerly known as Churg-Strauss syndrome, is an anti-neutrophil cytoplasmic antibody (ANCA) - associated primary systemic vasculitis of the small-to-medium sized vessels that leads to tissue and organ damage. Although its pathogenic background is not fully understood, an approach comprising nomenclature and classification criteria has facilitated its recognition during the last 25 years. The diagnosis framework provided by the Lanham diagnostic criteria (1984), the American College of Rheumatology classification criteria (1990) and the Revised International Chapel Hill Consensus Conference nomenclature of vasculitides (2012) includes asthma, blood and tissue eosinophilia, paranasal sinus abnormalities, neuropathy and non-fixed pulmonary infiltrates in the setting of particular histopathological findings, namely "eosinophil-rich and necrotizing granulomatous inflammation often involving the respiratory tract and necrotizing vasculitis predominantly affecting small to medium vessels"(1). However, these criteria were not originally designed as diagnostic tools and diagnostic criteria still lack at the moment. The ongoing Diagnostic and Classification Criteria in Vasculitis (DCVAS) study has already settled the premises to develop and validate diagnostic criteria for systemic vasculitides ${ }^{(2)}$.

In this report, we present a case of ANCAnegative EGPA that required transbronchial biopsy (TBB) for histopathological proof. We will discuss the diagnostic approach, emphasizing the spectrum of clinical features and paraclinical findings that could assist the diagnosis.

\section{Case presentation}

A 58-year-old woman complaining of progressive exertional dyspnea and dry cough was admitted to our clinic in June 2016. The patient without any known allergies was a non-smoker but had significant professional exposure to air pollutants working as a librarian for 16 years. We noticed serious pulmonary disease records over the last three years. She had an "atypical" obstructive lung disease initially classified as asthma that occasionally associated mild restriction (noted on spirometry) and interstitial lung abnormalities (revealed on thoracic computed tomography)- right lung interstitial infiltrates in September 2015 that vanished two months later as well as partially confluent bibasal reticular opacities and micronodules two months prior to current admission. Imaging findings suggestive of centrilobular pulmonary emphysema, bilateral bronchiectasis and infracentrimetric mediastinal lymphadenopathy were also identified. The patient had been recently on treatment with salmeterol/fluticasone $25 / 250 \mu \mathrm{g}$, ipratropium $20 \mu \mathrm{g}$ and montelukast $10 \mathrm{mg} /$ day.

The patient's medical history included euthyroid autoimmune thyroiditis and chronic mild anemia. She also had significant family history: her mother was suffering from rheumatoid arthritis and her daughter had asthma.

In April 2016 the patient was admitted to an allergology department where negative allergy tests, eosinophilia $(1500 / \mu \mathrm{l})$ and moderate biological inflammatory syndrome were recorded. She was then referred to a parasitologist who ran additional tests in order to exclude an infectious disease: serum antibodies to HIV and hepatitis viruses, IgG 
antibodies to Toxocara canis and Trichinella spiralis, larvoscopic method for Strongyloides stercoralis, coproparasitological exam as well as TPHA test were all negative. An upper gastrointestinal endoscopy was performed, displaying large hiatal hernia, esophagitis and antral gastritis.

On admission to our clinic, the patient had prolonged expiratory phase, left basal lung crackles and rare diffuse sibilant rales. Blood tests revealed mild anemia of chronic disease (microcytic anemia, hemoglobin of $10.2 \mathrm{~g} / \mathrm{dl}$, low serum iron, high ferritin level-

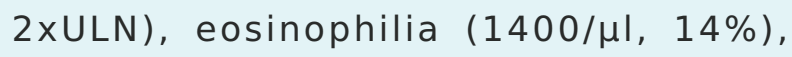
biological inflammatory syndrome, mild hy poalbuminemia, polyclonal hypergammaglobulinemia and elevated total IgE level (3xULN).

We spotted persistent proteinuria of nephritic pattern ( $1.5 \mathrm{~g} / 24$ hours). The cardiac, abdominal and pelvic ultrasonography were within normal range. Mixed ventilatory dysfunction $\left(\mathrm{FEV}_{1}=43 \%\right.$, FVC $=57 \%$ ) and normal DLCO value were noticed on pulmonary function tests. The thoracic CT scan identified interlobular septal and bronchial wall thickening, diffuse patchy bilateral ground-glass opacification and mediastinal lymphadenopathy. Additional blood tests revealed negative ANCA, anti-nuclear, Ro and La antibodies as well as tumoral biomarkers (alpha- fetoprotein, carcinoembryonic antigen, CA 19-9); the rheumatoid factor was twice the upper limit of normal. On otorhinolaryngological examination chronic maxillary polypous rhinosinusitis was noticed.

A fibrobronchoscopy was performed, indicating intact bronchial mucosa with scarce mucous secretions. Bronchoalveolar lavage (BAL) identified eosinophilia (5.8\%) and no tumoral cells or evidence of bacterial/fungal infection, whereas the histopathological examination of the TBB specimen displayed leukocytoclastic necrotizing vasculitis and tissue eosinophilia. In light of these results, the diagnosis of EGPA seemed suitable.

\section{Discussion}

Our patient had an eosinophilic non-allergic asthma phenotype as proven by eosinophilia on BAL fluid cytology and negative allergy testing ${ }^{(3)}$. Apart from BAL, airway tissue biopsy and induced sputum identifying high eosinophil count are usually used to diagnose the eosinophilic asthma ${ }^{(3)}$. As these examinations are not always accessible, blood eosinophilia has been assigned as a predictive marker for sputum eosinophil count although it is an inconsistent finding in asthmatic patients and does not always correlate with sputum eosinophilia(3). Nevertheless, it does correlate well with the 
severity of asthma (recurrent exacerbations, high disease burden) ${ }^{(3-5)}$. Regardless of the facts mentioned above, the significant blood eosinophilia ( $>10 \%$ ) drew our attention because it occurs rarely in asthmatic patients ${ }^{(6)}$. Persistent biological inflammatory syndrome and multiple organ (lung, kidney) involvement were highly suggestive of a systemic inflammatory disease. As paraclinical workup for infectious diseases and malignancies was negative, a systemic autoimmune disease seemed plausible (either a collagenosis or a primary vasculitis). The clinico-biological setup (asthma, eosinophilia) and negative autoantibodies (anti-nuclear, Ro and La antibodies) were not applicable to a collagenosis, guiding us towards a primary vasculitis.

Our patient fulfilled five of the ACR 1990 Criteria for the classification of ChurgStrauss syndrome, namely asthma, eosinophilia, non-fixed pulmonary infiltrates, paranasal sinus abnormalities and extravascular eosinophils. As mentioned above, these criteria were designed for classification (not diagnostic) purposes, implying that a biopsy-proven vasculitis can be classified as EGPA with a sensitivity of $85 \%$ and a specificity of $99.7 \%$ if at least four of these criteria are met $^{(6)}$. We managed to obtain a biopsy specimen via a minimally invasive procedure (TBB) that was able to identify two pathognomonic features of EGPA.

Although it is commonly stated that surgical lung biopsy provides conclusive pathologic evidence, TBB has showed some promising results in a small study conducted by Schnabel et al in 1997: 4 out of 6 EGPA patients with nasal/paranasal histopathological confirmation had a positive $\mathrm{TBB}^{(7)}$. Subsequently, only few cases of EGPA diagnosed by TBB have been reported ${ }^{(8-10)}$, indicating a low yield of this procedure. However, given its high profile safety, it should be considered an alternative diagnostic technique in $\mathrm{EGPA}^{(10)}$.

We noticed an ANCA-negative EGPA phenotype that occurs in $40 \%-70 \%$ of cases and is usually linked to the eosinophilic phase (i.e. organ damage mediated by eosinophilic infiltration ${ }^{(1)}$. However, renal involvement and histopathological evidence of vasculitis strongly indicated the emergence of the vasculitic phase.

Moreover, an ANCA-negative phenotype usually associates cardiomyopathy rather than glomerulonephritis, as opposed to our case $^{(11)}$.

These findings emphasize the fact that in EGPA the clinical phases and ANCA patterns frequently overlap and do not always follow the chronological sequence, making the diagnosis even more confusing.

In conclusion, EGPA often raises diagnostic difficulties. In the absence of diagnostic criteria, it is mandatory to be aware of the clinical and biological features highly suggestive of EGPA. Whenever possible, a (minimally invasive) biopsy technique should be performed for histopathological evidence of necrotizing vasculitis, eosinophilic infiltrates in tissues and granulomas().

Acknowledgements: The authors would like to thank Marius loan Balea, the exceptional pneumologist who performed the transbronchial biopsy. To our knowledge, this is the first reported case of eosinophilic granulomatosis with polyangiitis diagnosed by transbronchial biopsy in Romania.

Declaration of interest: The authors declare that there are no conflicts of interest. 


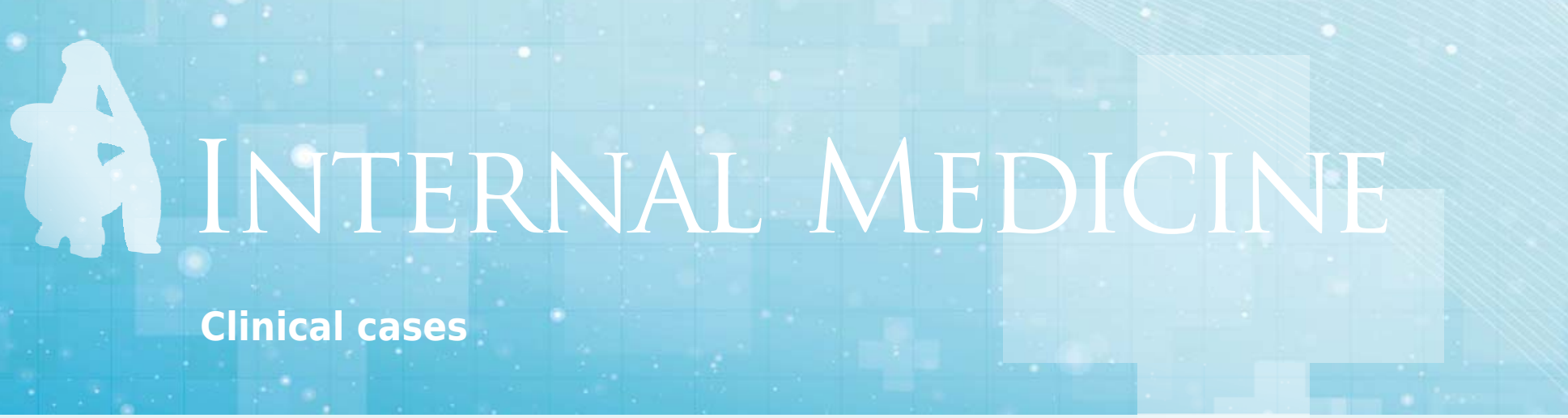

\section{References}

1. Gioffredi A, Maritati F, Oliva E, Buzio C. Eosinophilic granulomatosis with polyangiitis: an overview. Frontiers in immunology. 2014;5:549.

2. Luqmani RA, Suppiah R, Grayson PC, Merkel PA, Watts R. Nomenclature and classification of vasculitis update on the ACR/EULAR diagnosis and classification of vasculitis study (DCVAS). Clinical and experimental immunology. 2011;164 Suppl 1:11-3.

3. Tran TN, Khatry DB, Ke X, Ward CK, Gossage D. High blood eosinophil count is associated with more frequent asthma attacks in asthma patients. Annals of allergy, asthma \& immunology : official publication of the American College of Allergy, Asthma, \& Immunology. 2014;113(1):19-24.

4. Price $D B$, Rigazio A, Campbell JD, Bleecker $E R$, Corrigan CJ, Thomas M, et al. Blood eosinophil count and prospective annual asthma disease burden: a UK cohort study. The Lancet Respiratory medicine. 2015;3(11):849-58.

5. Walford HH, Doherty TA. Diagnosis and management of eosinophilic asthma: a US perspective. Journal of asthma and allergy. 2014;7:53-65.

6. Vaglio A, Buzio C, Zwerina J. Eosinophilic granulomatosis with polyangiitis (Churg-Strauss): state of the art. Allergy. 2013;68(3):261-73.

7. Schnabel A, Holl-Ulrich K, Dalhoff K, Reuter M, Gross WL. Efficacy of transbronchial biopsy in pulmonary vaculitides. The European respiratory journal. 1997;10(12):2738-43.

8. Ciledag A, Deniz H, Eledag S, Ozkal C, Duzgun N, Erekul S, et al. An aggressive and lethal course of ChurgStrauss syndrome with alveolar hemorrhage, intestinal perforation, cardiac failure and peripheral neuropathy. Rheumatology international. 2012;32(2):451-5.

9. Hara $Y$, Kanoh S, Fujikura $Y$, Kawano S, Misawa $K$, Kawana A. [A case of eosinophilic granulomatosis with polyangiitis with extra-vascular granuloma and eosinophilic vasculitis diagnosed by transbronchial lung biopsy]. Arerugi = [Allergy]. 2013;62(5):579-84.

10. Solans $R$, Bosch JA, Perez-Bocanegra $C$, Selva $A$, Huguet $P$, Alijotas $J$, et al. Churg-Strauss syndrome: outcome and long-term follow-up of 32 patients. Rheumatology. 2001;40(7):763-71.

11. Mouthon L, Dunogue B, Guillevin L. Diagnosis and classification of eosinophilic granulomatosis with polyangiitis (formerly named Churg-Strauss syndrome). Journal of autoimmunity. 2014;48-49:99-103. 